\title{
Do Children with Dyslexia Have Difficulty in Reading the Quranic Verses Too?
}

\author{
Shalinawati Ramli', Khairani Omar'1, Mohamad Ahsanullah El Baki¹, Shahlan Surat² \\ ${ }^{1}$ Faculty of Medicine and Health Sciences, Universiti Sains Islam Malaysia, Kuala Lumpur, Malaysia \\ ${ }^{2}$ Department of Teaching and Learning Innovation, Faculty of Education, Universiti Kebangsaan Malaysia, Bangi, \\ Malaysia \\ Email: shalinawati@usim.edu.my
}

Received 29 March 2016; accepted 22 May 2016; published 25 May 2016

Copyright (C) 2016 by authors and Scientific Research Publishing Inc.

This work is licensed under the Creative Commons Attribution International License (CC BY).

http://creativecommons.org/licenses/by/4.0/

(c) (i) Open Access

\begin{abstract}
Dyslexia, a type of learning disability, is a neurodevelopmental disorder that affects reading, writing and spelling in children. It is one of the commonest learning disorders among school-going children. The causes of dyslexia are multifactorial and are hereditary. The objective of this study was to determine if children with dyslexia have difficulty in reading the Quranic verses too. This was a cross-sectional study conducted at a government primary school in Kuala Lumpur. All standard one pupils, a total of 200 pupils, were screened for reading, writing and numerical difficulties by the school teachers in March, 2014 using LINUS screening tool, a standardized literacy screening tool adopted by all Malaysian schools. Students who failed the first LINUS screening were given intervention by the school teachers. Six months later, the research team reassessed the pupils who failed the Linus screening. Approximately 18\% (37 pupils) of the standard one pupils had dyslexia. of these, 33 of them were Muslims and were assessed if they had difficulty reading the Quranic verses by using Iqra', which is the basic reading material for Quranic verses. About $79 \%$ of them had difficulty reading the Quran. The majority of the children with dyslexia also had difficulty reading the Quranic verses. Thus remedial intervention for Muslim dyslexic children should also include learning to read the Quran.
\end{abstract}

\section{Keywords}

Dyslexia, Learning Disability, Primary School, Pupil, Quran

\section{Introduction}

Dyslexia is a type of specific learning disability. It is a neurodevelopmental disorder that affects the brain's 
ability to receive, process, store and respond to information (Peterson \& Pennington, 2012). The severity varies with each individual (Peterson \& Pennington, 2012). Children with dyslexia have problems in recognizing alphabets, reading accurately and fluently as well as spelling despite adequate instruction, normal intelligence and intact sensory abilities (Lyon, Shaywitz, S. E., \& Shaywitz, B. A., 2003).

Dyslexia was initially recognized in adults in the latenineteenth century and it was first reported among children in 1896. It is one of the most common problems among school-age children and the prevalence is in the range of $5 \%$ to $17 \%$ (Shaywitz, S. E. \& Shaywitz, B. A., 2003). Children with dyslexia appear physically normal just like any other children of similar age, possessing the intelligence and motivation for learning; however they have unexpected reading difficulty. Many parents have difficulty in accepting and understanding that their children have dyslexia because their children appear normal physically and have no problem in interacting with other children. Thus, intervention for these children is often delayed.

The causes of dyslexia are multifactorial. It is known to be familial and hereditary. The leading theory today is that it is due to subtle differences in the brain structure and functions, especially in the left hemisphere of the brain (Shaywitz, S. E. \& Shaywitz, B. A., 2003; Nation, Cocksey, Taylor, \& Bishop, 2010). The neurological disturbances can be caused by genetic, environmental toxins and pollution, maternal substance abuse and complications during pregnancy and delivery.

Most research on dyslexia has studied mainly on the English language. However, reading difficulties in other languages are also present and are now being studied as well. Dyslexia has been investigated in various countries; however most of the studies involved monolingual languages. Some of the studies were done in Greek (Porpodas, 1999), France (Sprenger-Charolles, Cole, Lacert, \& Serniclaes, 2000), Denmark (Van der Leij, Van Daal, \& De Jong, 2002) and Arabic countries (Elbeheri, Everatt, Reid, \& Al-Mannai, 2006). Research which looked into cross-linguistic studies of dyslexia showed that dyslexia is manifested differently in different languages (Smythe, Everatt, \& Salter, 2004). Therefore in the assessment of dyslexia, specific linguistic features of the language spoken by the individual should be considered.

The verses in the holy Quran are in the Arabic language whereby the letters (Hijahiyyah letters) differ from the alphabets used in the English and Malay language. We wonder if children with reading difficulties in the Malay language will also have similar difficulties in reading the Holy Quran. Hence, the objective of this study is to determine if children with dyslexia have difficulty in reading the Quranic verses too.

\section{Methodology}

This is a cross-sectional study conducted at a government Primary School in Kuala Lumpur. All standard one pupils in the school were included in the study. The pupils were screened for reading, writing and numerical difficulties by the school teachers in March, 2014 using LINUS screening tool. These pupils were then given the appropriate intervention by the school teachers.

LINUS is a Literacy and Numeracy Screening Programme adopted by all schools under the Malaysian Ministry of Education. This program is designed and developed as an enhancement of the previous program, ensuring that all pupils in primaryone are able to read, write and calculateat the end of primary three.

In this study, pupils who failed the first LINUS Screening assessment in March, 2014 were selected to undergo a second assessment by the researchers. The researchers consisted of a Family Medicine Specialist with Learning Disabiliy subspecialty, a lecturer from the Faculty of Medicine, USIM, a lecturer from the Faculty of Education UKM and trained research assistants.

The assessment conducted by the researchers consisted of 1) identifying alphabets 2) phonetics awareness 3 ) basic reading skill 4) writing skill 5) spelling and 6) identifying numbers and simple mathematics. Those who have difficulty in doing the above tasks are referred to the Family Medicine Specialist for further evaluation. If they are not able to identify the alphabets or had difficulty to produce the phonetic sounds, they are suspected to have dyslexia.

The Muslim pupils were also assessed if they could identify "hijaiyyah" letters, produce phonetic sounds of the letters and read Iqra' (1-6). Those who were able to read at least Iqra' 2 were considered to acquire basic reading skill of the Quranic verses. "Iqra' 1" is about identification of "Hijaiyyah" letters and sound of the letters while Iqra' 2 and above focus on reading words and simple sentences of the Quran.

To analyse the data, SPSS version 13 was used. Ethical approval to do the study was granted by the Islamic Science University of Malaysia. Permission to conduct the study at the chosen school was obtained from the 
Principal of the school and consent was also obtained from the parents of the pupils before participating in the study.

\section{Results}

A total of 200 primary one pupils in a government primary school in Kuala Lumpur were included in the study.In March 2014, LINUS screening was done by the school teachers to screen for pupils with reading and writing problem. Out of 200 pupils, 80 pupils failed the LINUS screening. These pupils were given the standard intervention by the school teachers.

In October, 2014, the researchers reassessed the 80 pupils for reading and writing difficulties. Five pupils did not attend school during the day of assessment and they were excluded from the study. Thus only 75 pupils were assessed (Table 1).

From the assessment, 37 pupils (18.5\% of 200 standard one pupils) were still not able to read and write fluently as expected for their age. They were suspected to have dyslexia. These pupils were referred to the Family Medicine Specialist for confirmation and to rule out other learnig problems such as Attention Deficit Hyperactive Disorder, Autism, Down syndrome and mental retardation. None of them had other problems besides dyslexia. Majority of the pupils were Muslims (33) (Table 2).

The 33 Muslim students who were suspected to have dyslexia were also assessed if they could identify "Hijaiyyah" letters and read the Iqra'. Of these pupils, 79\% (26) were not able to read Iqra' 1 or 2 (Figure 1).

The level of difficulties in reading Iqra' were divided into three levels. The lowest level was the ability of the pupils to identify the "Hijaiyyah" letters which are the basic unit of Iqra' similar to the alphabets in the English language. Forty-two percent of the dyslexic pupils who had difficulty in reading Iqra' could only identify the "Hijaiyyah" letters but were unable to read. Another $19 \%$ of them could produce single phonetic sound of the "Hijaiyyah" letters. None of them could read simple words of the Iqra'.

Table 1. Demographic characteristics of the pupils who failed LINUS screening.

\begin{tabular}{ccc}
\hline Variable (N $=\mathbf{7 5})$ & Frequency $(\boldsymbol{n})$ & Percentage (\%) \\
\hline Gender & & \\
Male & 48 & 64 \\
Female & 27 & \\
& & \\
Ethnic & & 88 \\
Malay & 66 & 9 \\
Indian & 7 & 3 \\
Others & 2 & \\
& & 88 \\
Religion & & 5 \\
Muslim & 66 & 7 \\
Hindu & 4 & \\
Christian & 5 &
\end{tabular}

Table 2. Demographic characterics of pupils who were suspected to have dyslexia.

\begin{tabular}{ccc}
\hline Variable $(\mathbf{N}=\mathbf{3 7})$ & Frequency $(\boldsymbol{n})$ & Percentage (\%) \\
\hline Gender & 25 & 33 \\
Male & 12 & 16 \\
Female & & \\
Ethnic & 33 & 44 \\
Malay & 3 & 4 \\
Indian & 1 & 1 \\
Others & & \\
Religion & 33 & 44 \\
Muslim & 2 & 3 \\
Hindu & 2 & 3 \\
Christian & & \\
\hline
\end{tabular}




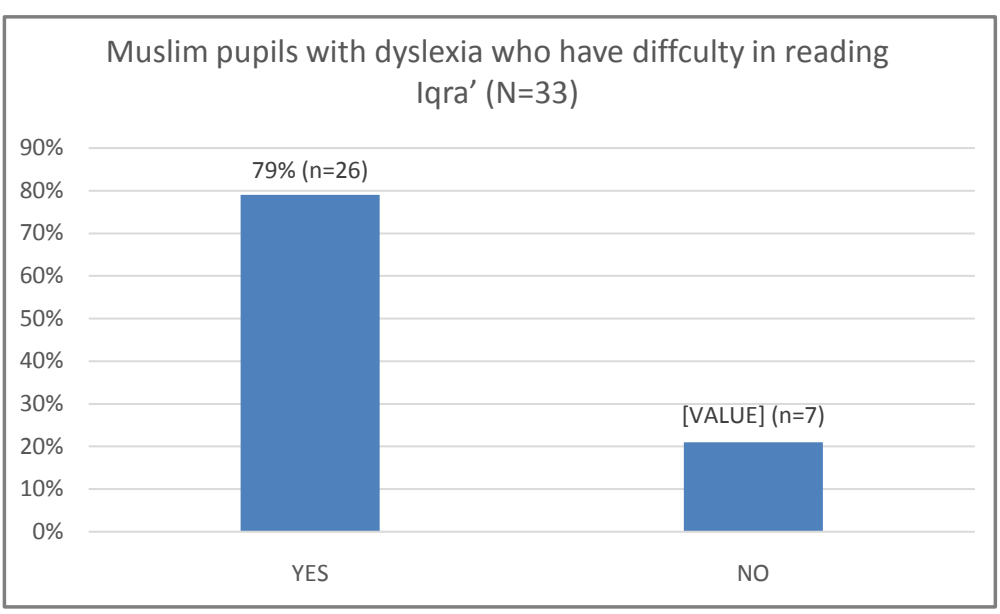

Figure 1. The proportion of Muslim pupils with dyslexia who have difficulty in reading Iqra'.

\section{Discussion}

In Malaysia, children with dyslexia have received increasing attention in the past few years. Previously, children with reading and writing difficulties were not identified by teachers in schools and were not given appropriate intervention. Thus, many children with dyslexia ultimately finished schooling without the ability to read fluently and write appropriately. They are considered slow learners and are often marginalized in schools. Many of them dropped out from school when they are unable to cope with the demanding academic syllabus.

Till now, there are not many studies done in Malaysia that have looked into the problem if the Muslim dyslexic children would also have difficulty in reading the Holy Quran. If these children do have problem in reading the Quran, then proper intervention is required to assist them. Quranic verses are being recited in the Muslim prayers and Quran is a holy book which every Muslim should learn to read. Hence, it is importantfor all Muslim children including the dyslexic children to have literacy in reading the Quran.

In this study, it was shown that majority (79\%) of the Muslim pupils who were suspected to have dyslexia also had difficulty in reading the Quran. Out of these pupils, 58\% were not able to identify hijaiyyah letters and only $19 \%$ were able to produce single phonetic sounds of the letters (refer to Table 3). None of them were able to join the phonetic sounds of the letters to produce simple words. However, there were 7 pupils (out of 33) who were able to read simple words of the Iqra'. Perhaps these children also had difficulty in reading the quran earlier but had undergone intensive intervention, in other words they had been taught to read the quran diligently by the parents or "ustaz/ustazah".

Dyslexia is a language-based learning disability as the severity of the problem varies across different language orthographies (Elbeheri, Everatt, Reid, \& Al-Mannai, 2006). Orthography literally means "the part of language concerned with letters and spelling”. Previous studies had shown that consistency of language orthography strongly predicts reading ability among children (Seymour, Aro, \& Erkskine, 2003; Landerl, Wimmer, \& Frith, 1997). This indicates that if the mapping between the letters and sound in a language is consistent then the acquisition of the language is easier. Some languages such as Italian, Spanish, Turkish, Greek and German have more transparent orthographies and readers find it easier to read (Spencer, 1999). The Malay language is considered to have a transparent orthography too since the mapping between the letters and sound is consistent. English has a non-transparent orthography while Arabic and Hebrew have both types of orthography (Beland \& Mimouni, 2001). In the transparent orthography, there is one-to-one association between letters and sound whereas in the non-transparent orthography the association between letters and sounds is diminished.

The Quranic verses are in Arabic language,hence it is expected that the readers would have some difficulties in learning to read the Quran.

Prior to understanding dyslexia in the context of the Arabic language, we have to recognize the relevant linguistic features and related cultural aspects of that language (Elbeheri, Everatt, Reid, \& Al-Mannai, 2006). For example, Arabic script is written in a cursive style with the letters being joined together by ligatures. It is read and written from the right to the left side in contrast with the English and Malay language. Capital letters 
Table 3. Level of difficulties in reading the Iqra'.

\begin{tabular}{ccc}
\hline Variable (N = 26) & Frequency (n) & Percentage (\%) \\
\hline Ability to identify "Hijaiyyah" letters & & \\
Yes & 11 & 52 \\
No & 15 & \\
& & 19 \\
Ability to produce single phonetic sounds & & 81 \\
of "Hijaiyyah” letters & 5 & \\
Yes & 21 & 0 \\
No & & 100 \\
Ability to read simple words in the Quran & & \\
(Iqra' 2) & 0 & \\
Yes & 26 & \\
No & & \\
\hline
\end{tabular}

are not used in the Arabic language; hence the letters are consistent in shape although some letters may be written in slightly different ways depending on the position of the letters within a word.

Nevertheless, in Malaysia, majority of the Muslims are Arabic illiterate. The Muslims are able to read the Quranic verses with the assistance of explicit guidance and “tajweed”. The meaning of the Quranic revelations is understood from translations into the Malay or English language. Despite that, dyslexic children still have difficulty in reading the Quran as shown in the findings.

There are some limitations in this study. The sample size was rather small as this study only included pupils in a school located inan urban area. Future studies should havea bigger sample size including pupils from different schools and rural areas.

\section{Conclusion}

In this study, it is revealed that most children who have difficulty in reading the Malay language or English language will also have difficulty in reading the Quran. Thus, remedial intervention for Muslim dyslexic children should also include learning to read the Quran as an additional component. Methods of teaching these dyslexic children may differ for different languages depending on the linguistic features of the language. Therefore, parents and teachers ought to be aware of this issue and a more comprehensive remedial intervention should be designed for Muslim students.

\section{References}

Beland, Z., \& Mimouni, Z. (2001). Deep Dyslexia in the Two Languages of an Arabic/French Bilingual Patient. Cognition Journal, 82, 77-126. http://dx.doi.org/10.1016/S0010-0277(01)00148-2

Elbeheri, G., Everatt, J., Reid, G., \& Al-Mannai, H. (2006). Dyslexia Assessment in Arabic. Journal of Research in Special Educational Needs, 6, 143-152. http://dx.doi.org/10.1111/j.1471-3802.2006.00072.x

Landerl, K., Wimmer, H., \& Frith, U. (1997). The Impact of Orthographic Consistency on Dyslexia: A German-English Comparison. Cognition, 63, 315-334. http://dx.doi.org/10.1016/S0010-0277(97)00005-X

Lyon, G. R., Shaywitz, S. E., \& Shaywitz, B. A. (2003). A Definition of Dyslexia. Annals of Dyslexia, 53, 1-14. http://dx.doi.org/10.1007/s11881-003-0001-9

Nation, K., Cocksey, J., Taylor, J. S. H., \& Bishop, D. V. M. (2010). A Longitudinal Investigation of Early Reading and Language Skills in Children with Poor Reading Comprehension. Journal of Child Psychology and Psychiatry, 51, 10311039. http://dx.doi.org/10.1111/j.1469-7610.2010.02254.x

Peterson, R. L., \& Pennington, B. F. (2012). Developmental Dyslexia. Lancet, 379, 1997-2007. http://dx.doi.org/10.1016/S0140-6736(12)60198-6

Porpodas, C. D. (1999). Patterns of Phonological and Memory Processing in Beginning Readers and Spellers of Greek. Journal of Learning Disabilities, 32, 406-416. http://dx.doi.org/10.1177/002221949903200506

Seymour, P. H. K., Aro, M., Erkskine, J. M. et al. (2003). Foundation Literacy Acquisition in European Orthographies. British Journal of Psychology, 94, 143-174. http://dx.doi.org/10.1348/000712603321661859

Shaywitz, S. E., \& Shaywitz, B. A. (2003). Dyslexia (Specific Reading Disability). Pediatrics in Review, 24, 147-153. http://dx.doi.org/10.1542/pir.24-5-147 
Smythe, I., Everatt, J., \& Salter, R. (2004). International Book of Dyslexia-A Cross-Language Comparison and Practice Guide (3nd ed.). Wileys. Chichester.

Spencer, K. (1999). Predicting Word-Spelling Difficulty in 7- to 11-Year Olds. Research in Reading Journal, $22,79-85$. http://dx.doi.org/10.1111/1467-9817.00091

Sprenger-Charolles, L., Cole, P., Lacert, P., \& Serniclaes, W. (2000). On Subtypes of Developmentaldyslexia: Evidence from Processing Time and Accuracy Scores. Canadian Journal of Experimental Psychology, 54, 87-103. http://dx.doi.org/10.1037/h0087332

Van der Leij, A., Van Daal, V., \& De Jong, P. (2002). Task Related Factors in Reading Efficiency of Dyslexicchildren. In L. Verhoeven, C. Elbro, \& P. Reitsma (Eds.), Precursors of Functional Literacy (pp. 229-245). Amsterdam: John Benjamins. http://dx.doi.org/10.1075/swll.11.16lei 